\title{
Evaluation of Short Wave Therapy Equipment Based On Brazilian Standards
}

\author{
Cristiane Regina Gruber and Pedro Miguel Gewehr* \\ Programa de Pós-Graduação em Engenharia Elétrica e Informática Industrial - CPGEI; Centro Federal de \\ Educação Tecnológica do Paraná - CEFET-PR; gewehr@cpgei.cefetpr.br; Av. 7 de Setembro, 3165; 80230-901; \\ Curitiba - PR - Brasil
}

\begin{abstract}
Short Wave Diathermy (SWD) equipment is used in physiotherapy and applied therapeutically using radio frequency $(R F)$ radiation of $27.12 \mathrm{MHz}$. This article presents the results of a survey related to SWD, showing data about the equipment, conditions of use, visual inspection and analysis of accompanying documents, having as reference the requirements of the Brazilian standards NBR IEC 601-1 and NBR IEC 601-2-3. Electrical safety tests were also carried out for the equipment and the installation. The results showed that manufacturers do not completely follow the standards and there is a lack of knowledge of these standards by the physiotherapists. Electrical safety tests presented measured values of equipment leakage current within the limits of the standards, but installation presented fails. One can conclude that it is necessary a greater awareness by manufacturers and professionals regarding the standards including electrical safety in order to assure the correct use of SWD equipment.
\end{abstract}

Key words: Short wave diathermy, biomedical equipment evaluation, electrical safety

\section{INTRODUCTION}

Short wave diathermy (SWD) therapy is an electromagnetic resource used in physiotherapy for the treatment of many diseases and pathologies. It is a form of RF radiation that operates in 27.12 $\mathrm{MHz}$ and can be applied in continuous or pulsed mode. It is used in therapy to produce a local heating of tissue by conversion of electromagnetic energy into thermal energy (HECS, 2003).

Electromagnetic energy, in the operation frequency of SWD, is known to present many biological effects. Exposure to RF radiation can result in beneficial or potentially damaging effects. The Brazilian Health Ministry classifies SWD equipment as high risk (class 3), for administrating kinds or types of energy intrinsically dangerous to the human body (MS, 1994). Although little information related to the possibilities of adverse effects by means of SWD is available, all kinds of electrotherapy present an inherent risk to the patient, if they are applied incorrectly or if malfunctioning equipment is used. Individuals are exposed to a certain quantity of electromagnetic energy everyday. However, the use of electrotherapeutic modalities exposes therapists, patients, students and other individuals to additional fields. An adequate practical use prevents additional exposures, eliminates problems and supplies an efficient treatment bringing more benefits to the patient.

The efficiency of a treatment depends on the

\footnotetext{
${ }^{*}$ Author for correspondence
} 
quality of the equipment and its correct functioning. Factors related to the equipment as utilization frequency, intense moving among many sites, inadequate handling, sudden temperature changes and equipment aging, cause incorrect functioning that can lead to problems of calibration (KLD, 2004). The best way to overcome these problems is to submit the equipment to periodic calibration and verification tests. To guarantee the efficiency of the treatment there is the need to implement some procedures that allow physiotherapists to assure a good functioning of their apparatus.

Considering the procedures above, there are several standards from the Brazilian Association of Technical Standards (ABNT), which establish certain functioning parameters and tests specifications for SWD equipment. The National Agency for Sanitary Vigilance (ANVISA) from the Health Ministry has defined on Resolution $\mathrm{n}^{\circ}$ 444/1999 the adoption of the Brazilian technical standard NBR IEC 601-1 (Electro Medical Equipment - Part 1: General safety requirements) (ABNT, 1994) and the particular Brazilian technical standards NBR IEC 601-2 for class and type tests (Mühlen, 2001). For SWD equipment, the standard NBR IEC 601-2-3 (Electro Medical Equipment - Part 2: Particular requirements for the safety of short wave therapy equipment) is used. This standard amends and complements the NBR IEC 601-1 and specifies the safety requirements of short wave therapy equipment. It establishes functioning parameters, control and tests of the equipment (ABNT, 1997).

The administration and managing of SWD equipment is a very little exploited issue by physiotherapists, possibly due to their lack of knowledge in technical tests as well as in the functioning of the equipment. Authors relate that little literature is available about revision tests and quality control of electrotherapy equipment, including SWD (Shields et al., 2003).

The objective of this article is to present and discuss the main results obtained through an evaluation of SWD equipment having as reference the Brazilian standards mentioned above.

The evaluation includes: a survey (general information, visual inspection and environment) as well as electrical safety tests. The evaluation was done in physiotherapy clinics to obtain the conditions of use and functioning of SWD equipment along with the available equipment as well as with the physiotherapists responsible for the equipment.

\section{MATERIALS AND METHODS}

\section{Survey and Preventive Maintenance}

Initially, the evaluation of the SWD therapy equipment was done by means of a survey (diagnosis verification) in 4 educational institutions and 3 private clinics of Curitiba (Brazil), along with the physiotherapists that were in charge of the equipment and using the available equipment to carry on the verification.

The survey was implemented through specially developed questionnaires based on the standards: NBR IEC 601-1 (ABNT, 1994) and NBR IEC 601-2-3 (ABNT, 1997).

The questionnaires contain questions with which general information about the equipment (manufacturer, model, operation and functioning, location, tests, maintenance, among others) is requested, as well as information about its utilization. The questionnaires were applied to 10 physiotherapists and answered by all of them.

The preventive maintenance is used for the increasing of equipment lifetime, having as consequence the reduction of costs and the increasing of equipment quality (Webster, 1998).

For a preventive maintenance program, the information that identifies the equipment (name, manufacturer, model, age, etc.) the location or sector to which it belongs, the state of the equipment (if it is in use or deactivated), the level of its utilization, etc. are all necessary. This information was gathered by means of questionnaires as it was previously described.

As researcher responsibility, record cards were used to store data concerned to the visual inspection of the equipment (12 items), consultation to the accompanying documents (16 items), environment description in which they operate and electrical safety tests.

At the end, 20 units of SWD therapy equipment were evaluated, from 7 manufacturers and 11 different models.

All the clinics agreed with the realization of the survey and made their equipment available to the necessary tests.

\section{Visual Inspection}

The inspection is a procedure used to check out the physical integrity of the equipment and to guarantee the appropriate requirements of safety 
and performance, including those requested by standards (Vieira, 1998).

According to the Brazilian standards (ABNT, 1994; ABNT 1997), the SWD equipment must have marks and identifications over both internal and external sides of the instrument. Among them are: power output declared in watts, load resistance to which the power is available, operation frequency in megahertz, model or equipment reference type, mains (power supply) voltage, equipment power input, network power output, classification, operation mode and warning symbols over access covers. As it was previously commented, the equipment is inspected based on the 12 items related with the studied standards (ABNT, 1994; ABNT 1997).

\section{Accompanying Documents}

All equipment must be accompanied by documents that show, at least, the instructions of use, a technical description and an address of reference, to which the user can report him(her)self. The accompanying documents must be considered part of the equipment (ABNT, 1994). The documents must contain general information of utilization (installation, handling and application), technical description (utilization frequency, power, load resistance, operation mode) and warnings.

\section{Environment Inspection}

The environment in which the equipment is utilized must be inspected and controlled to assure that metal objects are not present in the room and instead, stretchers and wood supports should be used.

The electrical installations of the rooms are considered below.

\section{Electrical Safety Tests}

Medical procedures usually expose the patients to a series of hazards, among them the possibility of an electric shock (Webster, 1998).

The electrical safety tests verify if the levels of leakage current from the enclosure (chassis) of the equipment to the earth, among others, are within the specified limits $(100 \mu \mathrm{A}$ for SWD instrument) according to the standard NBR 601-1 and specific standards of series NBR 601-2 from ABNT.

Measurements were also done on the supply voltages of the electrical installations in the sites where the equipment is used, making use of an electrical safety analyzer (Turbo tester from
Biotek, USA) designed to be used for biomedical equipment. This analyzer when connected to the receptacles (outlets) inside the room and the equipment measures the voltages of the receptacles as well as the leakage currents from the chassis to the earth for the equipment under test.

Other characteristics analyzed, regarding electrical safety, were the existence of the third conductor (protective earth conductor) of the installation and the verification of the plug of the equipment that must not have an adaptor from 3 to 2 pins.

\section{RESULTS}

\section{General Information}

The physiotherapists responsible for the SWD equipment answered the questionnaire to find out the general characteristics of use, whose main results are quantified below.

Concerning the date of the equipment purchase, it was known only for 4 (20\%) of the instruments.

When therapists were asked about their knowledge of the short wave therapy Brazilian standards (ABNT, 1994; ABNT, 1997), it was verified that $100 \%$ of the therapists did not have any knowledge about them.

Considering the frequency with which the instruments were periodically sent to maintenance, it was observed that: from 10 interviewed physiotherapists, $2(20 \%)$ have answered that the instruments are not sent to maintenance, $6(60 \%)$ have said that they go to maintenance annually, 1 $(10 \%)$ does not know and, $1(10 \%)$ that the equipment is sent to maintenance every 6 months or when it presents some kind of malfunction.

When questioned if, by the occasion of a new purchase of equipment, any kind of test is carried out, the following result was obtained: $6(60 \%)$ have not answered, $1(10 \%)$ has related that he(she) uses fluorescent lamp, 1 (10\%) has answered that he(she) turns the equipment on; 1 (10\%) has declared that he(she) executes the appropriate tests of the equipment and 1 (10\%) has said that he(she) makes the application according to the equipment (transcript from the answers).

The question "how does one know if the equipment is in good condition?" has shown: 5 $(50 \%)$ physiotherapists answered that they do not know, 2 (20\%) by verifying the heat from the probes, $1(10 \%)$ through the given maintenance and by watching its functioning, $1(10 \%)$ by means 
of an assessment of an electrical engineer and, 1 $(10 \%)$ when the instrument does not show any noise, keeps its intensity and frequency and presents a good conduction in the test with lamps. Concerning the item "uses and cares on the application with short wave therapy" 12 questions were elaborated, being one of them subjective. From the 10 physiotherapists, 9 (90\%) apply the therapy over the clothes of the patient, $1(10 \%)$ applies the therapy with metallic implants, 5 $(50 \%)$ have said that the cables stay over metallic parts, $6(60 \%)$ say that they use wood stretchers and $4(40 \%)$ use metallic stretchers.

Also, all 10 (100\%) physiotherapists do not apply the SWD in patients with implanted electric devices, test the patient's sensitivity before the application of therapy, do not use other equipment along with the SWD instrument, use temporizer to control the therapy, they take out hearing devices before the therapy and report that the cables do not stay in contact with the patient and the equipment does not overheat frequently.

Finally, regarding the subjective question "what is done when the patient reports that it is too warm on the local of the application of the therapy?" the answer was: $1(10 \%)$ physiotherapist did not say anything, $6(60 \%)$ said that they lower the intensity and $3(30 \%)$ reported that they interrupt the therapy.

\section{Visual Inspection}

From 20 verified instruments, 13 (65\%) presented both kinds of emission (continuous and pulsed) and 7 (35\%) presented just the continuous mode. All the instruments presented specifications of manufacturer and model.

Regarding to the kind of electrodes being used, 7 (35\%) were from the schliephack type and 12 were from the pad type. One instrument had no electrodes. Another instrument did not heat; one had a broken schliephack electrode support; one was without one of the supports that should be in number of 4 and in one else the cables did not connect firmly.

The other items inspected in the equipment are presented on table 1 and are related to data which is supposed to be marked on the equipment, according to the standards NBR 601-1 and NBR 601-2-3 (ABNT, 1994; ABNT, 1997).

Table 1 - Inspection of marks on the equipment $(n=20)$

\begin{tabular}{lcc}
\multicolumn{1}{c}{ Verified Items } & Presence & Absence \\
\hline Classification & $45 \%$ & $55 \%$ \\
Warning Symbols & $60 \%$ & $40 \%$ \\
Operation Frequency & $35 \%$ & $65 \%$ \\
Declared Power Output & $30 \%$ & $70 \%$ \\
Network Power Output & $50 \%$ & $50 \%$ \\
Temporizer Presence & $70 \%$ & $30 \%$ \\
Standards Citation & $20 \%$ & $80 \%$ \\
\hline
\end{tabular}

\section{Accompanying Documents Verification}

In this item, it was observed that, from the 20 evaluated instruments, $12 \quad(60 \%)$ were accompanied by their documents and 8 were not. Also, only two presented guarantee certificates. The data for the accompanying documents were taken from the previously commented standards and they are described on table 2 .

\section{Environment}

The rooms (in a total of 12), in which the SWD instruments were operating, were visually evaluated and the results analyzed. Three (15\%) of the instruments remained in a separated local from other electrothermophototherapy devices, although next to these; and $17(85 \%)$ stayed in a local or room along with those devices. Just in one place there was a Faraday cage and in it there were 6 SWD and one microwave diathermy instruments.

\section{Electric Safety Tests}

For the rooms, it was verified the presence or not of electrical installation with 3 conductors, e. g., 
including the protective earth conductor. From 12 evaluated rooms, 11 had receptacles with 3 conductors and only one had with 2 conductors. However, not all of the instruments used in the rooms whose receptacles had 3 conductors presented plugs with 3 pins.

From 20 instruments, $12(60 \%)$ had plugs with 3 pins, $6(30 \%)$ with two pins and $2(10 \%)$ with three pins but in a same horizontal line.
From 20 verified receptacles, 9 (45\%) have presented problems of wiring change between phase and neutral, 4 (20\%) have not presented the protective earth conductor and 7 (35\%) were found within the recommended practice (127 volts between phase and neutral conductors, 127 volts between phase and earth conductors and nearly zero volts between neutral and earth conductors).

Table 2 - Accompanying documents $(\mathrm{n}=12)$

\begin{tabular}{lcc}
\hline \multicolumn{1}{c}{ Verified Items } & Presence & Absence \\
\hline Mains (Power Supply) Frequency & $91.7 \%$ & $8.3 \%$ \\
Operation Frequency & $91.7 \%$ & $8.3 \%$ \\
Declared Power Output & $91.7 \%$ & $8.3 \%$ \\
Power Input & $16.7 \%$ & $83.3 \%$ \\
Network Power Output & $16.7 \%$ & $83.3 \%$ \\
Classification & $58.3 \%$ & $41.7 \%$ \\
Warning Declarations & $41.7 \%$ & $58.3 \%$ \\
Operation Mode & $91.7 \%$ & $8.3 \%$ \\
Equipment Description & $100 \%$ & $0 \%$ \\
Use Instructions & $100 \%$ & $0 \%$ \\
Application Cares & $66.7 \%$ & $33.3 \%$ \\
Technical Characteristics & $91.7 \%$ & $8.3 \%$ \\
Indications and Counter Indications & $91.7 \%$ & $8.3 \%$ \\
Indication for Receptacles with Three Conductors & $75 \%$ & $25 \%$ \\
Maintenance Address & $58.3 \%$ & $41.7 \%$ \\
Standards Citation & $66.7 \%$ & $33.3 \%$ \\
\hline
\end{tabular}

Concerning the item "leakage current", 16 instruments were tested. All tested devices presented values within the limits specified by the NBR 601-1 and NBR 601-2-3 for the measured cases (ABNT, 1994; ABNT, 1997), which was $100 \mu \mathrm{A}$. The four instruments that were not tested had plugs non-compatible with the input of the analyzer used for the measurements.

\section{DISCUSSION}

With the implementation of the verification and the tests, a great variety of answers and results were obtained.

The equipment purchase date was not known by the users for $16(80 \%)$ of the devices. This finding associated with the absence of guarantee certificates and other documents related to the equipment, make it difficult to the process of preventive maintenance, since for this purpose it is necessary that all documents and information related to the equipment is recorded and filled in. All 10 physiotherapists that were interviewed did not know about the ABNT standards, which specify tests and requirements for the installation and use of SWD therapy equipment. This can make the set up of an appropriate local for the treatment more difficult, the same may happen with the control of some safety parameters specified by the standards, as well as to verify if the instrument that is being used is working 
properly, since the standards bring important specifications for that control.

It was observed that there is great controversy mainly concerning the periodicity of maintenance, tests used at the acquisition, conditions of good functioning and equipment handling.

The visual inspection is an important item of equipment control. Many problems can be detected visually (Webster, 1998). The instruments were inspected in order to identify possible failure in its use condition, which could adversely affect the safety of the patient as well as the operator. The instruments must contain specifications according to the NBR IEC 601-1 and NBR IEC 601-2-3, but it is noticed that most of them do not present all the specifications. Also, $5(25 \%)$ of the evaluated instruments were presenting mechanical problems, demonstrating failure in the preventive maintenance process. Considering the 20 instruments visually evaluated, none was entirely in conformity with the standards.

The absence of accompanying documents makes it impossible for the user to consult them when there is a real need and in addition to that, it brings difficulty for the implementation of a maintenance program as commented previously. For only 12 $(60 \%)$ out of 20 instruments the presence of the documents was observed.

The environment must be visually evaluated to assure that the emitted radiation by the SWD equipment does not cause any interference in other devices and that metallic objects present in the area do not cause concentration of radiation (Shields et al., 2003). None of the 12 environments inspected was considered absolutely suitable to support the SWD therapy application, either by the presence of metal objects that collaborate with the concentration of radiation or by the presence of other electrothermofototherapy equipment that can be influenced by the SWD radiation. RF radiation emitted can interfere with other electrotherapy devices in a range of $3 \mathrm{~m}$ to $5 \mathrm{~m}$ (CSP, 1994). It is pointed out that only the documents of one SWD equipment manufacturer recommended the use of a Faraday's cage.

Concerning the electrical safety tests, it was observed that there are some faults on the electric installations what can expose the patient to electric shocks and/or damage to the equipment.

Finally, taking into account the results and the discussion above reported, some general conclusions can be presented.

1.In spite of the existence of Brazilian standards
(ABNT) which specify parameters of control and functioning for the correct practice of SWD therapy as well as with electro medical equipment in general, it is noticed that the standards, in most cases, are not known by the professionals of the biomedical area and consequently they are not followed. This allows the increasing of the hazards for the user as much as for the patients.

Thus, awareness by the physiotherapists that make use of this therapy is necessary, concerning the verification and control of their instruments, in order to assure their correct functioning and to avoid risks for the patient's treatment.

2.The manufacturers must also specify the information required by the standards, considering the documents of the equipment and the necessary marks on it. That would greatly help the process of preventive maintenance.

3.Considering the item electrical safety, it is important for the physiotherapists that the project and the implementation of the electrical installations are carried out only by qualified professionals, thus avoiding problems and possible risks involving the equipment and the installation, protecting both patient and operator from damage. The manufacturers also must have a deeper concern about the project and the construction of their instruments, whose requirements of electrical safety are defined in standards, so that these needs are followed and rigorously respected under the penalty of not proportioning electrical protection when in use.

\section{ACKNOWLEDGEMENTS}

C. R. Gruber thanks CAPES-Brazil for the scholarship.

\section{RESUMO}

Equipamentos de diatermia por ondas curtas (DOC) são utilizados em clínicas de fisioterapia e aplicados terapeuticamente, utilizando radiação de radiofreqüência (RF) em 27,12 MHz. Este artigo apresenta os resultados de uma pesquisa diagnóstica para equipamentos de DOC mostrando dados relativos aos equipamentos, condições de uso, inspeção visual e análise dos documentos acompanhantes tendo como referência os requisitos descritos nas normas brasileiras NBR 
IEC 601-1 (geral) e NBR IEC 601-2-3 (específica). Além disso, apresentam-se os resultados de testes de segurança elétrica efetuados nos equipamentos e nas instalações onde os mesmos são utilizados. Os resultados em geral mostraram que os fabricantes não seguem as normas para as especificações tanto do equipamento quanto do ambiente e dos documentos acompanhantes, e que há falta de conhecimento das normas por parte dos fisioterapeutas. Os testes de segurança elétrica envolvendo correntes de fuga dos equipamentos obtiveram valores dentro dos limites especificados pelas normas, porém algumas instalações elétricas apresentaram falhas. Conclui-se que deve haver uma maior conscientização por parte dos fabricantes e dos profissionais em relação aos requisitos das normas incluindo a segurança elétrica, com o intuito de assegurar o correto funcionamento do equipamento e não fornecer riscos para o tratamento do paciente.

\section{REFERENCES}

Associação Brasileira de Normas Técnicas (1994), NBR IEC 601-1: Equipamento Eletromédico - Parte 1: Prescrições Gerais para Segurança. Rio de Janeiro: ABNT.

Associação Brasileira de Normas Técnicas (1997), NBR IEC 601-2-3: Equipamento Eletromédico - Parte 2: Prescrições Particulares para a Segurança de Equipamento de Terapia por Ondas Curtas. Rio de Janeiro: ABNT.

Brasil. Ministério da Saúde (1994), Portaria n²043/94. Diário Oficial [da] República Federativa do Brasil. Brasília.

Chartered Society of Physiotherapy (1994), Guidelines for the safe use of pulsed short wave therapy equipment. Physiotherapy, 80, 233-35.

Healthy Environments and Consumer Safety (2004), Guidelines for limiting radio frequency exposureshort wave diathermy-safety code 25. Disp. in: http://www.hc-sc.gc.ca/hecs-sesc/ccrpb/publication/ 83ehd98/chapter1.htm. Access in: 14 abr. 2004.

KLD Biossistemas (2004), Calibrações. Disp. in: http://www.kld.com.br/calibracoes. Access in: 16 mar. 2004.

Mühlen, S. S. (2001), Certificação de qualidade em equipamentos médico-hospitalares no Brasil. In: Congreso Latinoamericano de Ingeniería Biomédica, Habana. Anais... Habana.
Shields, N.; O'Hare, N.; Boyle, G. and Gormley, J. (2003), Development and application of a quality control procedure for short wave diathermy units, Med. Biol. Eng. Comput., 41, 62-68.

Webster, J. G. (1998), Medical instrumentation: application and design. New York: John Wiley and Sons.

Vieira, J. B. M. (1998), Setor de manutenção de equipamentos eletromédicos: avaliação $e$ implementação. M. Sc. Thesis, CPGEI/CEFET-PR, Curitiba, Brasil. 


\section{FOLHA EM BRANCO}

